\title{
Improvement of Engine Combustion with Diesel-Biodiesel Blend Using Nanoparticles
}

\author{
Ninawe G. ${ }^{1}$, Tariq $\mathbf{M .}^{2}$ \\ ${ }^{1,2}$ Department of Mechanical Engineering, Sam Higginbottom University of Agriculture, \\ Technology and Sciences, Allahabad, India.
}

\begin{abstract}
Various studies have demonstrated the characteristics of diesel fuel by adding biodiesel. Furthermore, nano additives can be added to these fuels for the improvement of engine combustion. The present investigation concerns improvement in combustion characteristics of a single cylinder, four-stroke, water cooled, direct injection, diesel engine with cotton seed methyl ester using multiwalled carbon nanotubes (MWCNT). The results of combustion and performance characteristics depends on the study of the combustion parameters, like cylinder pressure, rate of heat release, mechanical efficiency and volumetric efficiency; these parameters have been determined and presented in the following sections.
\end{abstract}

Keywords: Biodiesel, nanoparticles, engine, combustion, CNTs

\section{INTRODUCTION}

It has been experienced by many researchers that Biofuel is a cleaner approach for the transportation sector to reach all the energy demands. During combustion process in engine the environmental benefits we get are decreased carbon dioxide emissions relative to the amount that was undisturbed from atmosphere. There is high pressure on water resources because of requirement of water for producing biofuels which is already emphasized and will be seen in many regions [1].

The commercialization of biofuel projects enforces the employment either in direct or indirect way. These projects give mechanism to employ all the category peoples including skilled and unskilled workers for various departments. The government had already initiated programs for urban, industrial and commercial applications. These programs aimed to evaluate energy from vegetable wastes, agriculture residue, municipal wastes, and industrial wastes.[2] Therefore, as an alternative choice to fossil fuels, the biofuel is considered as a supreme energy source in future which have potential to decrease vehicle emissions, maximize supply of energy and provide income for farmers [3].

Transesterification, also called alcoholysis, is the displacement of alcohol from an ester by another alcohol in a process similar to hydrolysis, besides that an alcohol is utilized instead of water. Thus, fatty acid methyl esters (FAME) also known as biodiesel produced by transesterification can be employed as an alternative fuel for diesel engines.[4]In this current research, the biodiesel was produced from the oil extracted from cottonseed. By using the transesterification process, the cottonseed oil (Triglycerides esters) has been converted to methyl esters. The conversion of vegetable oil (Triglyceride Esters) to methyl esters through transesterification process, which reduces the molecular weight to one-third, reducing the viscosity by a factor of 8 and increasing the volatility. Properties of different fuel and fuel blends are shown in table 1.

Table 1 : Properties of different fuel and fuel blends used in testing.

\begin{tabular}{|l|c|c|c|c|}
\hline Properties & Diesel base & B10 & B15 & B20 \\
\hline Kinematic Viscosity $\left(\mathrm{mm}^{2} / \mathrm{sec}\right)$ & 2.25 & 2.38 & 2.56 & 2.73 \\
\hline Density $\left(\mathrm{kg} / \mathrm{m}^{3}\right)$ & 790 & 802 & 810 & 817 \\
\hline Calorific value $(\mathrm{MJ} / \mathrm{kg})$ & 43.25 & 42.89 & 42.16 & 41.35 \\
\hline Flash point $\left({ }^{\circ} \mathrm{C}\right)$ & 56 & 71.60 & 80.25 & 88.5 \\
\hline
\end{tabular}

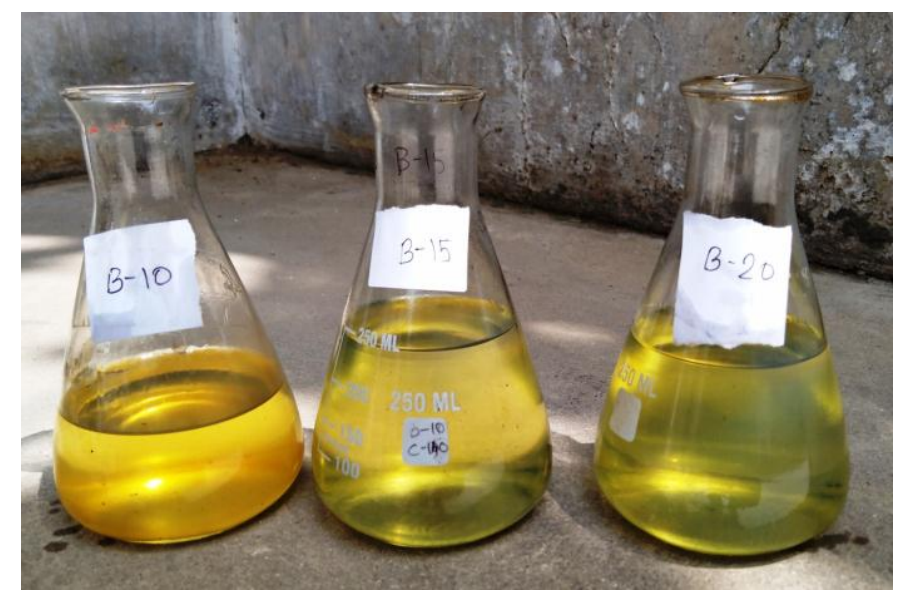

Fig. 1. Samples of diesel-biodiesel blend in conical flask.

Multi-walled carbon nanotubes (MWNTs) were provided from Platonic Nanotech Private Limited, India with purity more than $97 \%$. The average diameter of the carbon nanotubes varied from $10-15 \mathrm{~nm}$ and their length from 2-10 $\mu \mathrm{m}$. Carbon nanotubes acts as an useful additives for improving the quality of the fuels[5]. The CNTs added to all fuel blends were mixed for $5 \mathrm{~min}$ to get the homogeneous 
emulsion fuel. Table 2 shows the properties and of the MWCNTs.

Table 2: Properties of MWCNTs

\begin{tabular}{|l|l|l|}
\hline Specification & Unit & Standard \\
\hline Diameter & $\mathrm{nm}$ & $10 \sim 15 \mathrm{~nm}$ \\
\hline Length & $\mathrm{um}$ & $2-10$ microns \\
\hline Purity & $\%$ & $>97 \%$ \\
\hline Ash Content & $\%$ & $<2 \%$ \\
\hline $\mathrm{Fe}$ & $\mathrm{mg} / \mathrm{kg}$ & $<4000$ \\
\hline $\mathrm{Al}$ & $\mathrm{mg} / \mathrm{kg}$ & $<3500$ \\
\hline $\mathrm{Mo}$ & $\mathrm{mg} / \mathrm{kg}$ & $<800$ \\
\hline Specific Surface Area & $\mathrm{m} 2 / \mathrm{g}$ & $250 \sim 270 \mathrm{~m} 2 / \mathrm{g}$ \\
\hline Bulk Density & $\mathrm{g} / \mathrm{cm} 3$ & $0.06 \sim 0.09 \mathrm{~g} / \mathrm{cm} 3$ \\
\hline
\end{tabular}

\section{EXPERIMENTAL SETUP}

The experimental setup consists of a single cylinder, fourstroke, VCR (Variable Compression Ratio) Diesel engine which was connected to eddy current type dynamometer for loading with its main parameters are shown in Table. 3. An onboard computer system is used to perform the common combustion calculations to eliminate the use of tables and complex calculations.

Table 3: Specifications of all equipment and devices used in experiments.

\begin{tabular}{|l|l|}
\hline Engine type & 4-stroke VCR diesel engine \\
\hline Number of cylinders & One \\
\hline Bore $\times$ stroke & $87.5 \times 110 \mathrm{~mm}$ \\
\hline Swept volume & $661 \mathrm{cc}$ \\
\hline Compression ratio & $17.5: 1$ \\
\hline Rated power & $3.5 \mathrm{~kW}$ at $1500 \mathrm{rpm}$ \\
\hline Fuel injection timing & $23^{\circ}$ BTDC \\
\hline Dynamometer type & $\begin{array}{l}\text { Eddy current, water cooled with } \\
\text { loading unit }\end{array}$ \\
\hline
\end{tabular}

\section{RESULTS AND DISCUSSION}

In this experimental investigation different fuel blends (B0, $\mathrm{B} 10$, B15, B20, B10C50, B10C100, B10C150, B15C50, $\mathrm{B} 15 \mathrm{C} 100, \mathrm{~B} 15 \mathrm{C} 150, \mathrm{~B} 20 \mathrm{C} 50 \mathrm{~B} 20 \mathrm{C} 100$, B20C150) were prepared. The blending of biodiesel and diesel fuel was done in a $500 \mathrm{ml}$ flask which was directly poured in the fuel tank. The experiments were performed by varying the loads on the engine to obtain different speeds.

\subsection{Pressure -Crank angle diagram}

The peak pressure depends on the quantity of fuel taking part in the uncontrolled combustion stage, which is dominated by the spray envelope of the injected fuel and delay period [6]. The peak pressure for the B0 fuel blend is 52.91 bar at $7^{0}$ crank angle after TDC with the base engine at variable loads.
Table 4 shows the peak pressure attained at the crank angle after TDC for all the fuel blends.

From the data it is observed that the peak pressure got decreased for the following fuel blends - B10C100, B10C150, $\mathrm{B} 15, \mathrm{~B} 15 \mathrm{C} 50, \mathrm{~B} 15 \mathrm{C} 100, \mathrm{~B} 15 \mathrm{C} 150$ and $\mathrm{B} 20 \mathrm{C} 150$ when compared with neat diesel fuel. This may be because of high viscosity and density of the cotton seed biodiesel. The increase in cylinder pressure is observed for following fuel blends - B10, B10C50, B20, B20C50 and B20C100 when compared with neat diesel fuel. The increase in cylinder pressure for these fuel blends were may be due to the better air fuel mixture formation rates, as a result of low fuel viscosity compared to raw vegetable oil. Hence the addition of nanoparticles to the fuel blends have shown positive effects for some of the blends to achieve higher peak pressure [7].

Table 4: Peak pressure obtained for all fuel blends

\begin{tabular}{|r|l|l|l|}
\hline Sr. no & Fuel blend & $\begin{array}{l}\text { Peak pressure } \\
(\text { Bar })\end{array}$ & $\begin{array}{l}\text { Crank angle } \\
\text { after TDC }\end{array}$ \\
\hline 1. & B0 & 52.91 & $7^{0}$ \\
\hline 2. & B10 & 53.63 & $7^{0}$ \\
\hline 3. & B10C50 & 53.73 & $8^{0}$ \\
\hline 4. & B10C100 & 52.56 & $8^{0}$ \\
\hline 5. & B10C150 & 52.18 & $8^{0}$ \\
\hline 6. & B15 & 52.48 & $8^{0}$ \\
\hline 7. & B15C50 & 52.62 & $8^{0}$ \\
\hline 8. & B15C100 & 52.16 & $8^{0}$ \\
\hline 9. & B15C150 & 52.62 & $8^{0}$ \\
\hline 10 & B20 & 55.08 & $8^{0}$ \\
\hline 11 & B20C50 & 53.20 & $8^{0}$ \\
\hline 12 & B20C100 & 54.93 & $8^{0}$ \\
\hline 13 & B20C150 & 52.73 & $9^{0}$ \\
\hline
\end{tabular}

\subsection{Net heat release}

The fluctuation of the heat release rate against crank angle at full load condition for all the fuel blends are shown in table 5 . It can be observed that the heat release is decreased for the fuel blends B10C100, B15, B15C50, B15C100, B15C150, $\mathrm{B} 20 \mathrm{C} 50, \mathrm{~B} 20 \mathrm{C} 100$ and $\mathrm{B} 20 \mathrm{C} 150$ when compared to neat diesel. Hence, it is noticed that the pre-mixed combustion phase is lesser for all these fuel blends as compared to that of diesel. This may be because of the poor vaporization and atomization of fuel which results in poor air-fuel mixing rate and gradual combustion of the vegetable oil [8]. Therefore, better burning occurs in the diffusion phase. It is clear that the premixed heat release of $\mathrm{B} 10 \mathrm{C} 100, \mathrm{~B} 15, \mathrm{~B} 15 \mathrm{C} 50, \mathrm{~B} 15 \mathrm{C} 100$, $\mathrm{B} 15 \mathrm{C} 150, \mathrm{~B} 20 \mathrm{C} 50, \mathrm{~B} 20 \mathrm{C} 100$ and $\mathrm{B} 20 \mathrm{C} 150$ fuel blends is lower than that of diesel fuel; hence the thermal efficiency is decreased. The B10, B10C50, B10C150 and B20 fuel blends shows a higher heat release rate as compared to diesel fuel. 
Hence the addition of CNTs to the fuel blends have shown higher heat release rate for some of the fuel blends [9].

Table 5: Peak heat release rate obtained for all fuel blends

\begin{tabular}{|c|c|c|}
\hline Sr. no & Fuel blend & $\begin{array}{c}\text { Peak Heat release rate } \\
\qquad(\mathrm{J} / \mathrm{deg})\end{array}$ \\
\hline 1. & B0 & 31.99 \\
\hline 2. & B10 & 36.11 \\
\hline 3. & B10C50 & 33.46 \\
\hline 4. & B10C100 & 30.04 \\
\hline 5. & B10C150 & 32.28 \\
\hline 6. & B15 & 31.48 \\
\hline 7. & B15C50 & 31.75 \\
\hline 8. & B15C100 & 30.98 \\
\hline 9. & B $15 C 150$ & 31.48 \\
\hline 10 & B20 & 36.29 \\
\hline 11 & B20C50 & 30.87 \\
\hline 12 & B20C100 & 26.07 \\
\hline 13 & B20C150 & 31.40 \\
\hline
\end{tabular}

\subsection{Mechanical Efficiency}

To evaluate mechanical efficiency, firstly friction power was determined which is based on Willan's line method. Figure. 2 shows the variations of mechanical efficiency with load for different fuel blend. The results showed that there is decrease in efficiency for blends with higher doses of CNTs when compared with neat diesel for higher loads, as the viscosity increases with increase of biodiesel concentration in the blended fuels. It was also noticed that for medium loads the mechanical efficiency of blends with CNTs was better in comparison with neat diesel fuel operation.

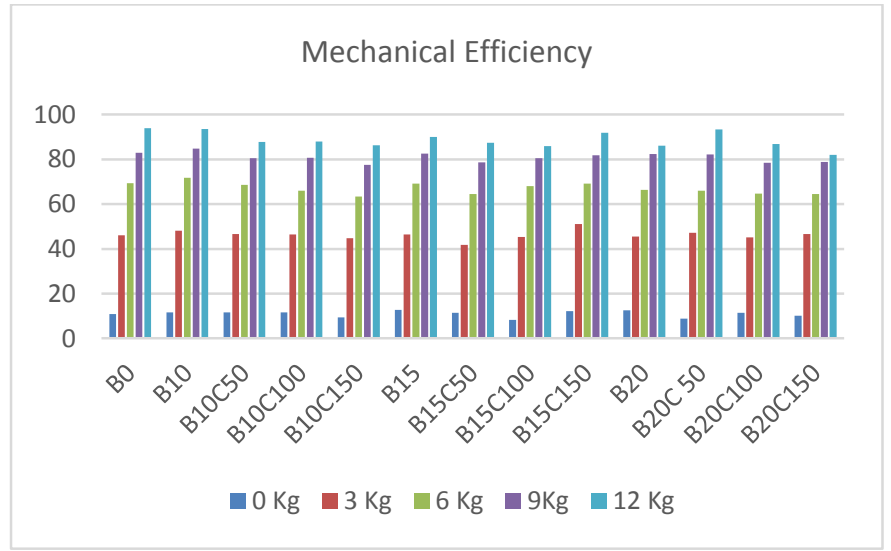

Figure. 2. Variation of mechanical efficiency for all the blends with different loads.

\subsection{Volumetric Efficiency}

The variation of volumetric efficiency with different loads for all fuel blend is as shown in Fig. 3. It was noticed that there was significant variations in the volumetric efficiency throughout the operating range concerning individual fuel blend tested, which agrees with [10]

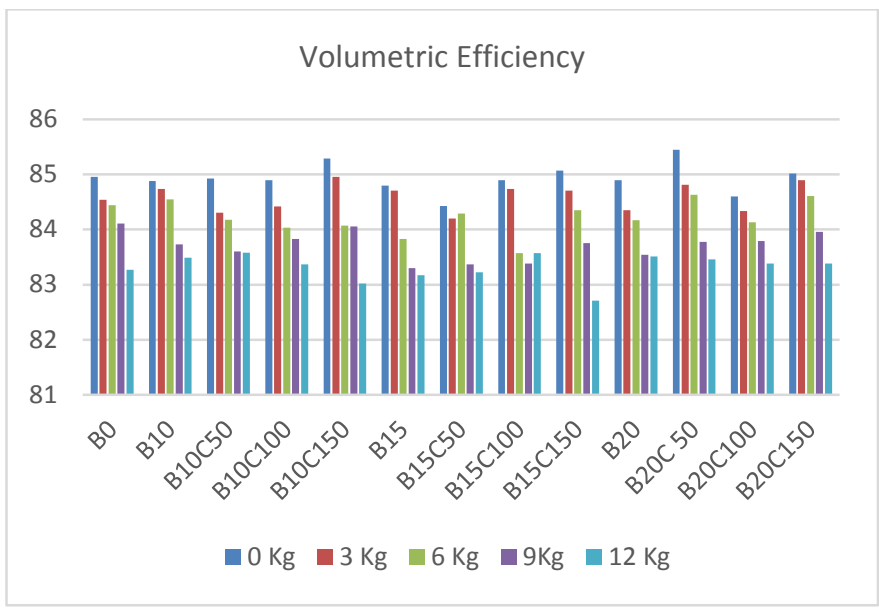

Figure. 3. Variation of volumetric efficiency for all the blends with different loads.

\section{CONCLUSION}

Cottonseed oil extract biodiesel can be mixed with diesel very well and directly used in a diesel engine without any modification. Heat release rate and thermal efficiency increases as the percentage of nanoparticles in diesel-biodiesel blends is increased. The increase in cylinder pressure was observed for some fuel blends with the addition of CNTs as additives. The volumetric efficiency for B20C50 fuel blend was higher when compared with other fuel blends and neat diesel fuel for higher loads. The mechanical efficiency was found to be lowered because of addition of CNTs for higher loads.

Based on the experiments, it is concluded that cotton seed biodiesel with CNTs as additives can be implemented as an alternative fuel for conventional diesel engines without any major modifications.

\section{REFERENCES}

[1] Weldemichael, Y., and Assefa, G., 2016 "Assessing the energy production and GHG (greenhouse gas) emissions mitigation potential of biomass resources for Alberta," J. Clean. Prod., 112, pp. 4257-4264

[2] Gaurav, N., Sivasankari, S., Kiran, G., Ninawe, A. and Selvin, J., 2017 "Utilization of bioresources for sustainable biofuels: A Review," Renew. Sustain. Energy Rev., 73, pp. 205-214

[3] Raman, S., and Mohr, A., 2014 "Biofuels and the role of space in sustainable innovation journeys," J. Clean. Prod., 65, pp. 224-233 
[4] Fukuda, H., Kondo, A., and Noda, H., 2001 "Biodiesel fuel production by transesterification of oils," J. Biosci. Bioeng.

[5] Hosseini, S., H., Taghizadeh-Alisaraei, A., Ghobadian, B., and Abbaszadeh-Mayvan, A., 2017 "Performance and emission characteristics of a CI engine fuelled with carbon nanotubes and dieselbiodiesel blends," Renew. Energy, 111, pp. 201-213

[6] Kumar, M., S., Ramesh, A., and Nagalingam, B., 2001 "Complete Vegetable Oil Fueled Dual Fuel Compression Ignition Engine," SAE Tech. Pap., 2001-Novem pp. 441-448

[7] Balamurugan, T., and Nalini, R., 2014 "Experimental investigation on performance, combustion and emission characteristics of four stroke diesel engine using diesel blended with alcohol as fuel," Energy, 78, pp. 356-363

[8] Mani, M., Subash, C., and Nagarajan, G., 2009 "Performance, emission and combustion characteristics of a DI diesel engine using waste plastic oil," Appl. Therm. Eng., 29, pp. 2738-2744

[9] Elango, T., and Senthilkumar, T., 2011 "COMBUSTION AND EMISSION CHARACTERISTICS OF A DIESEL ENGINE FUELLED WITH JATROPHA AND DIESEL OIL BLENDS," 15, pp. 1205-1214

[10] Sharma, D., Soni, S., Pathak, S., Engineers, 2005 " undefined Performance and emission characteristics of direct injection diesel engine using neem-diesel blends." 